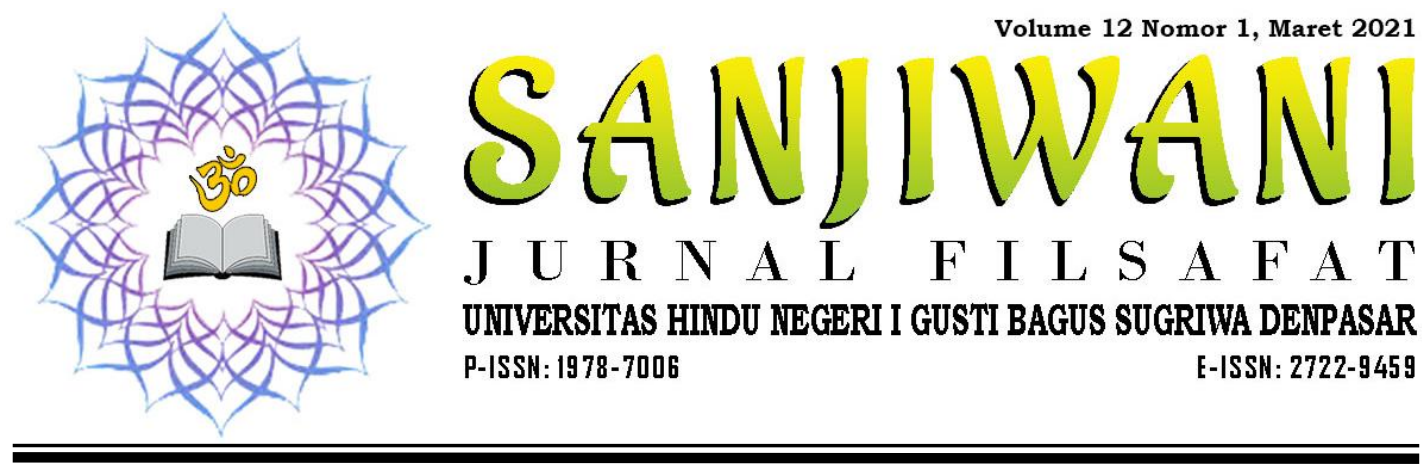

\title{
Konstruksi Banten Gebogan pada Era Golobalisasi di Desa Abiantuwung, Kecamatan Kediri, Kabupaten Tabanan
}

\author{
Pande Putu Toya Wisuda1, I Nyoman Subrata ${ }^{2}$ \\ Universitas Hindu Negeri I Gusti Bagus Sugriwa Denpasar ${ }^{1,2}$ \\ toyawisuda@yahoo.com ${ }^{1}$, inym.subrata@gmail.com ${ }^{2}$
}

\begin{tabular}{|c|c|}
\hline Keywords: & ABSTRACT \\
\hline $\begin{array}{l}\text { Construction; } \\
\text { banten gebogan; } \\
\text { globalization era. }\end{array}$ & $\begin{array}{l}\text { Banten is the means used by Balinese Hindus to worship God. } \\
\text { One of them is the banten gebogan. Banten gebogan now a days uses } \\
\text { not only fruits, snacks, flowers and other food products, but has } \\
\text { begun to use factory made canned drinks. Three formulations of the } \\
\text { problem can be stated, namely (1) What is the form of banten } \\
\text { gebogan in the era of globalization in Abiantuwung Village, Kediri } \\
\text { District, Tabanan Regency? (2) Why in the era of globalization, the } \\
\text { people of Abiantuwung Village, Kediri District, Tabanan Regency } \\
\text { use a variety of canned drinks in making offerings of gebogan? and } \\
\text { (3) What are the implications of offering banten gebogan in the era } \\
\text { of globalization in Abiantuwung Village, Kediri District, Tabanan } \\
\text { Regency? } \\
\text { This research use a qualitative approach. The data collection } \\
\text { technique was done by observing, interviewing, and studying } \\
\text { documents. The validity of the data was obtained by using the } \\
\text { transcription technique. The informants are determined in a } \\
\text { proposive manner, and the researcher himself is the main } \\
\text { instrument assisted by an interview guide, digital camera, laptop, } \\
\text { and writing instruments. After verification, the data were analyzed } \\
\text { using two theories, namely the theory of globalization and the } \\
\text { theory of sociocultural systems. } \\
\text { The form of banten gebogan can be divided into two parts } \\
\text { according to the times, namely Banten Gebogan Traditional and } \\
\text { Banten Gebogan Modern. As for the reasons that make people make } \\
\text { modern offerings, namely: Yajna Offerings of Gratitude to God, Art } \\
\text { and Aesthetic, and Practical, Effective and Efficient. The } \\
\text { implications of this modern offering is the spiritual degradation and } \\
\text { cultural transformation. }\end{array}$ \\
\hline
\end{tabular}




\begin{tabular}{|c|c|}
\hline Kata Kunci & ABSTRAK \\
\hline $\begin{array}{l}\text { konstruksi; } \\
\text { banten gebogan; } \\
\text { era globalisasi }\end{array}$ & $\begin{array}{l}\text { Banten adalah sarana untuk memuja Tuhan dalam } \\
\text { umat Hindu Bali. Salah satu diantaranya jenis banten tersebut } \\
\text { adalah banten gebogan. Banten gebogan dewasa ini bahan- } \\
\text { bahannya tidak hanya menggunakan buah-buahan, jajan, } \\
\text { bunga dan hasil pangan lainnya, tetapi mulai menggunakan } \\
\text { minuman kaleng buatan pabrik. Dengan demikian dapat } \\
\text { dikemukakan tiga rumusan masalah, yaitu (1) Bagaimana } \\
\text { bentuk banten gebogan pada era golobalisasi di Desa } \\
\text { Abiantuwung, Kecamatan Kediri, Kabupaten Tabanan? (2) } \\
\text { Mengapa pada era globalisasi masyarakat Desa } \\
\text { Abiantuwung, Kecamatan Kediri, Kabupaten Tabanan } \\
\text { menggunakan aneka ragam minuman kaleng dalam } \\
\text { pembuatan banten gebogan? dan (3) Bagaimana implikasi } \\
\text { banten gebogan pada era golobalisasi di Desa Abiantuwung, } \\
\text { Kecamatan Kediri, Kabupaten Tabanan? } \\
\text { Penelitian ini menggunakan pendekatan kualitatif. } \\
\text { Teknik pengumpulan data dilakukan dengan observasi, } \\
\text { wawancara, dan studi dokumen. Validitas data diperoleh } \\
\text { dengan teknik trangulisasi. Informan ditentukan secara } \\
\text { proposive, dan peneliti sendiri sebagai instrumen utama } \\
\text { dibantu dengan pedoman wawancara, Kamera Digital, } \\
\text { Laptop, dan alat tulis. Setelah dilakukan verifikasi, data } \\
\text { dianalisis dengan dua teori yakni teori Globalisasi, dan teori } \\
\text { Sistem Sosiokultural. } \\
\text { Bentuk bantengebogan dapat dibagi menjadi dua bagian } \\
\text { sesuai perkembangan jaman, yakni Banten Gebogan } \\
\text { Tradisional dan Banten Gebogan Modern. Adalapun alasan } \\
\text { yang membuat orang membuat banten gebogan modern, yaitu: } \\
\text { Yajña Persembahan Wujud Syukur Kehadapan Tuhan, Seni } \\
\text { dan Estetis, dan Praktis, Efektif dan Efisien. Adapun } \\
\text { implikasi dari banten gebogan modern ini adalah terjadinya } \\
\text { Degradasi Spiritual dan Transformasi Kebudayaan. }\end{array}$ \\
\hline
\end{tabular}

\section{PENDAHULUAN}

Umat Hindu di Bali hampir tiap-tiap hari melaksanakan upacara keagamaan. Berbagai yajña dipersembahkan sebagai sujud bakti kita terhadap Ida Sang Hyang Widhi Wasa sebagai pencipta. Praktek keagamaan masyarakat Bali yang beragama Hindu lebih banyak diwujudkan dalam bentuk ritual (upacara agama). Ruang lingkup yajña tidak hanya dalam bentuk upacara keagamaan, tetapi melingkupi segala bentuk pengabdian, kebijaksanaan, dan dana punia (bersedekah) secara tulus ikhlas, dan penuh keyakinan tanpa pamerih (Wiana, 2007: 32).

Upacara keagamaan merupakan tradisi yang menjadi ciri khas pada perilaku sosial dan sistem gagasan masyarakat Hindu Bali. Secara luas upacara 
hadir melingkupi siklus hidup dan berbagai kegiatan sosial di dalam kehidupan masyarakat Hindu Bali. Upacara merupakan bagian penting mengiringi sistem beragama orang Hindu Bali sejak dahulu. Berbagai yajñ yang dipersembahkan dapat dibagi menjadi lima macam, yang disebut dengan panca yajña, yaitu dewa yajña, rsi yajña, pitra yajña, manusia yajña, bhuta yajña. Dewa yajña, yaitu persembahan kehadapan para dewa. Rsi yajña, yaitu persembahan kehadapan para orang suci, seperti para rsi, pendeta, dan juga kehadapan para guru. Pitra yajña, yaitu persembahan kehadapan leluhur dan juga orang tua. Manusia yajña, yaitu persembahan kehadapan manusia, sedangakan bhuta yajña, yaitu persembahan kehadapan para bhuta atau roh yang menghuni alam bawah (Tim Penyusun, $2003: 1-3$ )

Dalam menyelenggarakan ritual keagamaan, umat Hindu di Bali menggunakan banyak sarana, salah satu di antaranya menggunakan berbagai jenis banten. Banten-banten yang dimaksud antara lain baten daksina, banten peras, banten pengambean, banten taman pulagembal, banten sesayut, banten tebasan, banten pengulapan, banten pabeyakawonan, banten benbangkit, baten gebogan, dan sebagainya. Di antara berbagai jenis banten tersebut, banten gbogan sering digunakan dalam upacara keagamaan terutama upacara dewa yajña. Banten gebogan bahan-bahannya terbuat dari buah-buahan, jajan, bunga dan hasil pangan lainnya dilengkapi dengan canang serta sampiyan gebogan. Semua sarana tersebut disusun dan dirangkai di atas wadah yang disebut dulang. Bentuk banten gebogan menyerupai sebuah gunung, semakin ke atas semakin lancip dan di atasnya dihiasi canang atau sampiyan gebogan. Akan tetapi pada era globalisasi pembuatan banten gebogan umat Hindu di Desa Abiantuwung banten tersebut mulai ditambah dengan menggunakan aneka ragam minuman yang diproduksi oleh pabrik seperti Pocari sweat, Larutan, Yakul, Ale-Ale, Teh Gelas, dan sebagainya. Pembuatan banten gebogan dengan menggunakan berbagai jenis minuman tersebut berbeda dengan sebelumnya. Artinya, banten gebogan awalnya dibuat dengan menggunakan sarana-sarana berupa berbagai jenis jajan, buah-buahan, bunga, canang, dan sampiyan gebogan. Penggunaan berbagai jenis minuman belakangan ini pada banten gebogan menarik untuk digali dan diteliti secara mendalam mengenai bentuk, alasanalasan yang mendorong dan implikasi perubahan banten gebogan tersebut.

\section{METODE}

Berdasarkan kasus diatas maka penelitian ini berbentuk penelitian deskriptif kualitatif. Penelitian ini datanya disajikan dalam bentuk teks naratif, kata-kata, ungkapan, pendapat, gagasan yang dikumpulkan oleh peneliti dari beberapa sumber sesuai dengan teknik pengumpulan data. Analisisnya mengarah pada pemaparan yang lebih konkret tentang Konstruksi Banten Gebogan Pada Era Globalisasi Di Desa Abiantuwung, Kecamatan Kediri, Kabupaten Tabanan.

Secara keseluruhan penelitian ini meliputi empat tahapan kerja, yaitu (1) tahap pengumpulan data, (2) tahap pengolahan data, (3) tahap sintesis, (4) tahap penulisan hasil penelitian. Pada tahap pengumpulan data dilakukan penjajagan, observasi non partisipasi, dan wawancara dilakukan kepada rohaniawan, 
maupun warga masyarakat desa abiantuwung untuk menanyakan alasan-alasan yang melandasi, bentuk, dan implikasi banten gebogan modern.

Data yang terkumpul dari observasi dan wawancara direduksi, dipilahpilah atau diklasifikasikan sesuai dengan fokus penelitian. Dari hasil wawancara dan dan observasi merupakan emik yang selanjutnya disintesakan dengan etik dan teori. Selanjutnya dilakukan penulisan laporan akhir penelitian terhadap penelitian lapangan setelah disintesakan dengan konsep dan teori yang relevan.

\section{PEMBAHASAN}

\subsection{Bentuk Banten Gebogan Tradisional dan Modern}

\subsubsection{Bentuk Banten Gebogan Tradisional}

Tradisi dalam kebudayaan adalah suatu struktur kreativitas yang sudah ada sebelumnya. Dalam tradisi ini juga mengandung arti keberadaan suatu kebudayaan yang tidak terpisahkan dengan masa lalu. Tradisi adalah sesuatu yang menghadirkan masa lalu pada era sekarang. Sehingga kebudayaan suatu masyarakat dalam konsepsi tradisi merupakan kontinuitas masa lalu bagi masa kini dan akan datang (Purba, 2007:2).

Dari pengertian tersebut dapat disimpulkan bahwa masyarakat tradisional merupakan masyarakat yang melangsungkan kehidupannya berdasar pada patokan kebiasaan adat-istiadat yang ada di dalam lingkungannya. Kehidupan mereka belum terlalu dipengaruhi oleh perubahan-perubahan yang berasal dari luar lingkungan sosialnya, sehingga kehidupan masyarakat tradisional cenderung statis.

Masyarakat Hindu di Bali khususnya masyarakat Desa Abiantuwung tidak bisa lepas dengan tradisi melaksanakan berbagai macam ritual keagamaan, di dalam melaksanakan tradisi ritual keagamaan sudah pasti terdapat berbagai jenis sarana upacara / bebantenan. Dari berbagai ragam sarana upacara / bebantenan, salah satu diantaranya adalah banten gebogan. Dari penjelasan di atas dapat disimpulkan terkait dengan bentuk banten gebogan tradisional adalah banten gebogan yang biasanya terdiri dari kumpulan beranekaragam buahbuahan, jajan atau bunga dihiasi sampian gebogan diujungnya yang disusun sesuai pakem-pakem yang ada sehingga keliatan rapi dan indah diatas sebuah dulang (sebuah tempat untuk menyusun buah-buahan, jajan dan bunga) membentuk kerucut meyerupai sebuah gunung yang dapat dilihat seperti gambar berikut. 


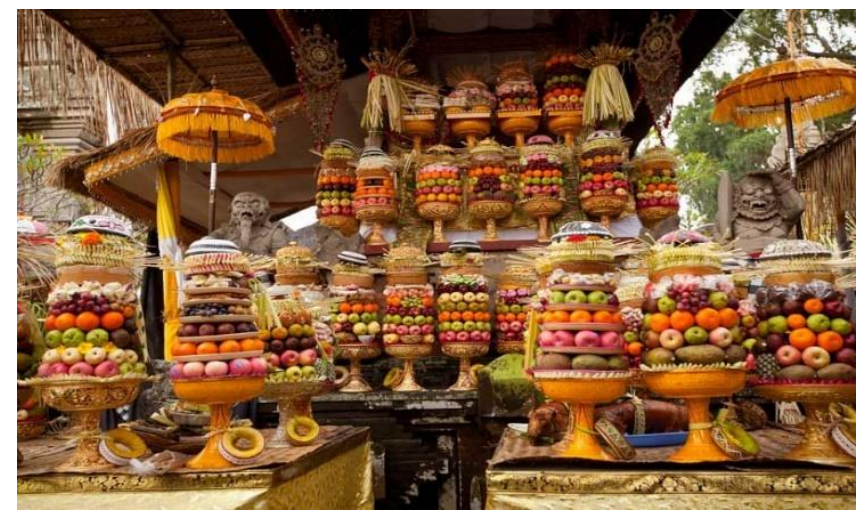

Gambar 1: Pembuatan Banten Gebogan

Sumber : (http://www.infobintaro.com)

\subsubsection{Bentuk Banten Gebogan Modern}

Istilah modern yang merujuk pada segala hal yang baru, berbau teknologi dan pengembangan ilmu pengetahuan telah menyajikan berbagai perkembangan pesat dalam membentuk mindset dan gaya hidup masyarakat. Secara etimologi, kata modern merupakan bahasa Latin "Modernus" yang dibentuk dari dua kata "modo dan ernus" yang menunjuk pada arti periode waktu masa kini (Martono, 2012: 80). Artinya, modern terkait dengan segala sesuatu yang baru yang berbeda dengan sesuatu yang lama, misalnya dalam cara hidup, dan aktivitas manusia yang berbeda dari masa sebelumnya. Martono juga menyebutkan istilah modernisasi, yakni sebuah proses perubahan dari keadaan lama (tradisional) menuju keadaan yang baru (modern). Dalam Kamus Bahasa Indonesia, istilah modern berarti sikap dan cara berpikir serta bertindak sesuai tuntunan zaman (KBBI, 2008: 1035).

Terkait dengan uraian di atas, bentuk gebogan umat Hindu di desa Abiantuwung yang dulunya terkesan tradisional dan mengikuti pakem-pakem yang ada, nampaknya kini sudah mulai mengalami perubah sesuai perkembangan jaman maupun pengaruh dari modernisasi yang telah menjadikan terjadinya suatu dinamika. Modernisasi menyeruak di segala bidang termasuk dalam bidang agama, khususnya menyangkut masalah banten gebogan. Banten gebogan yang dulunya terkesan sederhana dan hanya menggunakan bahan-bahan alami dari hasil bumi, dan tumbuh-tumbuhan, tetapi nampaknya dengan pengaruh modernisasi, banten gebogan sudah mengalami pergeseran dan perubahan ke arah modernisasi, yakni dengan menggunakan berbagai bahan dari hasil pabrikan, baik berupa minuman kaleng dan sebagainya, yang dapat dilihat seperti gambar berikut ini. 


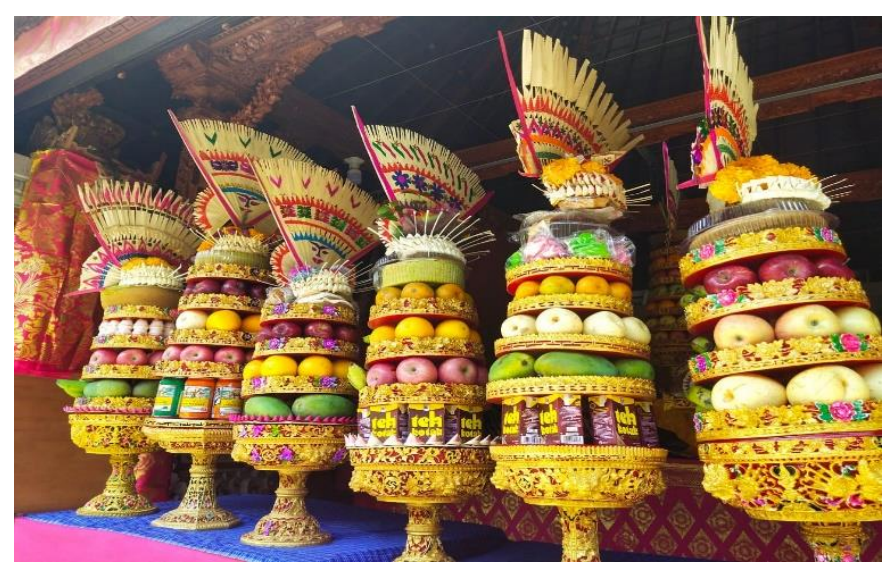

Gambar 2: Banten Gebogan Modern

Sumber : (Dokumen : Penulis, 2020)

\subsection{Alasan Pembuatan Banten Gebogan Modern}

\subsubsection{Yajña Persembahan Wujud Syukur Kehadapan Tuhan}

Secara Umum, tujuan agama Hindu yakni untuk mencapai kebahagiaan rohani dan kesejahteraan jasmani (moksartham jagadhitha ya ca iti dharma). Pelaksanaan realitas agama Hindu di Bali diwujudkan dengan mempersembahakan banten upakara. Banten upakara adalah sebuah wujud persembahan yang bertujuan agar terjadi keharmonisan antar manusia sebagai pemberi persembahan kepada yang dipersembahkan (Oka, $1997: 25)$.

Dari uraian di atas banten gebogan merupakan suatu persembahan yang tulus iklas kepada Tuhan. Banten gebogan menunjukan rasa sujud bakti kehadapan Tuhan. Manusia tidak bisa lepas dari pada kekuatan di luar nalar yang mewarnai kehidupan manusia. Rasa terimakasih manusia terhadap sang pencipta diekspresikan dengan berbagai cara. Salah satu diantaranya adalah dengan menghaturkan banten gebogan. Seperti yang diungkapkan dalam wawancara oleh $\mathrm{Ni}$ Ketut Reka sebagai berikut:

...iraga manumadi ke gumine puniki janten sampun wenten sane ngardi, sane ngardi irage, jagat miwah isinyane wantah ida sang hyang widhi wasa. Iraga dados jatma sampun sepatutne ngaturang agayubagya sampun kapaica maurip ring jagate, iraga dados jatma sampun ngemolihan kerahayuan, kemertan lan luir ipun. titiang ngaturang banten gebogan punika wantah ngaturang suksmaning manah lan anagayubagaia sareng sane ngardi jagate puniki sangkaning hati sane tulus majeng Hyang Parama Kawi. Dumugi ida sang hyang widhi sane ngardi jagate puniki stata ngicening kerahayuan, pemargi sane becik...

Terjemahannya:

...kita lahir ke dunia ini sudah pasti ada yang mengadakan, yang membuat kita ada, dunia beserta isinya adalah tidak lain Tuhan itu sendiri. Kita sebagai makhluk ciptaan Tuhan sudah sepantasnya bersyukur sudah diberi kehidupan di dunia ini, kita hidup di dunia ini sebagai manusia sudah di berikan kesehatan, kesejahteraan dan lain sebaianya. Saya membuat banten gebogan ini tidak lain sebagai wujud menghaturkan rasa terimakasih dan wujud syukur dengan 
hati yang tulus iklas kehadapan Tuhan Yang Maha Esa. Somoga Tuhan Pencipta alam beserta isinya ini senantiasa memberikan kesehatan dan jalan yang terbaik dalam kehidupan ini... (wawancara, 11 Juli 2020).

Pernyataan informan diatas menunjukkan bahwa, manusia sebagai makhluk religius tidak bisa terlepas dengan yang bersangkutan dengan sesuatu kekuatn yang Adikodrati yang menciptakan alam beserta isinya. Manusia di dunia ini merupakan salah satu makhluk hidup dijagat raya ini yang telah dikaruniai kelebihan pikiran olehNya. Manusia hidup di dunia ini juga diberikan berbagai kesehatan, kesejahteraan dan lain sebagainya oleh-Nya. Dengan segala nikmat yang telah diterima oleh manusia tersebut, sudah sewajarnya manusia tersebut berterimakasih kehadapan Tuhan sebagai pencipta alam semesta beserta isinya. Berbagai cara dilakukan oleh manusia untuk mendekatkan diri kehadapan Tuhan itu sendiri, dan berbagai cara ditempuh oleh manusia untuk mengungkapkan rasa terimakasih dan wujud syukur kehadan Tuhan, salah satu diantaranya dengan menghaturkan banten gebogan.

\subsubsection{Seni dan Estetis}

Menurut Person dalam Greertz (1973: 122), salah satu wujud kebudayaan adalah seni. Dimana perwujudan seni selalu berhubungan dengan penggunaan simbol, sebagaimana dalam bahasa yang menyiratkan suatu bentuk pemahaman bersama diantara warga masyarakat pendukungnya. Perwujudan seni merupakan suatu kesatuan karya yang dapat menjadi ekspresi individual, social, maupun budaya, yang dimana isi dari wujud seni sebagai substansi ekspresi yang menekankan pada berbagai tema, interpretasi atau pengalaman hidup penciptanya dalam bentuk tanda secara verbal maupun visual.

Terkait dengan nilai seni estetika yang terkandung di dalam banten gebogan hasil wawancara dengan Ni Wayan Susi Lestari menyatakan bahwa:

...Tiang ngaryanin banten gebogan nganggen sarana merupa minuman kaleng miwah minuman saking pabrikan lianan wantah tiang seneng nyingakin bentuk gebogane yen sampun dirangkai becik yen kecingakin, rapi, indah lan seni...

Terjemahannya:

...saya membuat banten gebogan menggunakan bahan berupa minuman kaleng dan minuman lainnya dari hasil pabrikan bahwa saya suka melihat bentuk gebogannya kalau sudah selesai dirangkai bagus kelihatannya, rapi, indah, dan seni... (wawancara, 8 Agustus 2020).

Senada yang diungkapkan oleh Ayu Suliati mengatakan bahwa:

...yen tiang ngaryanin banten gebogan puniki saking bahan minuman kaleng lan minuman saking pabrikan lianan wantah nuutin perkembangan jaman, akeh anak sane cingakin tiang ngaryanin banten gebogan nganggen minuman kaleng, lebih seni cingakin tiang ketimbang banten gebogan sane biasane...

Terjemahannya:

...kalau saya membuat banten gebogan ini menggunakan bahan dari minuman kaleng dan minuman hasil dari pabrikan lainnya karena 
mengikuti jaman, banyak orang yang saya lihat membuat banten gebogan yang menggunakan minuman kaleng, lebih seni saya lihat dibandingkan dengan banten gebogan yang biasanya...(wawancara, 9 Agustus 2020).

Data di atas menunjukkan bahwa mereka yang membuat banten gebogan dengan beragam minuman kaleng dari hasil pabrikan bahwa mereka senang karena banten gebogan itu bisa tertata lebih rapi, lebih bagus dipandang dan kelihatan indah lebih-lebih mereka yang membuat banten gebogan dari minuman kaleng tersebut mengikuti trend perkembangan jaman saat ini.

Peneliti sedang menyaksikan dan sambil mewawancarai informan dengan santai serta sesekali ikut membantu informan sedang merangkai banten gebogan menggunakan minuman kaleng hasil pabrikan dapat dilihat dalam gambar di bawah ini.

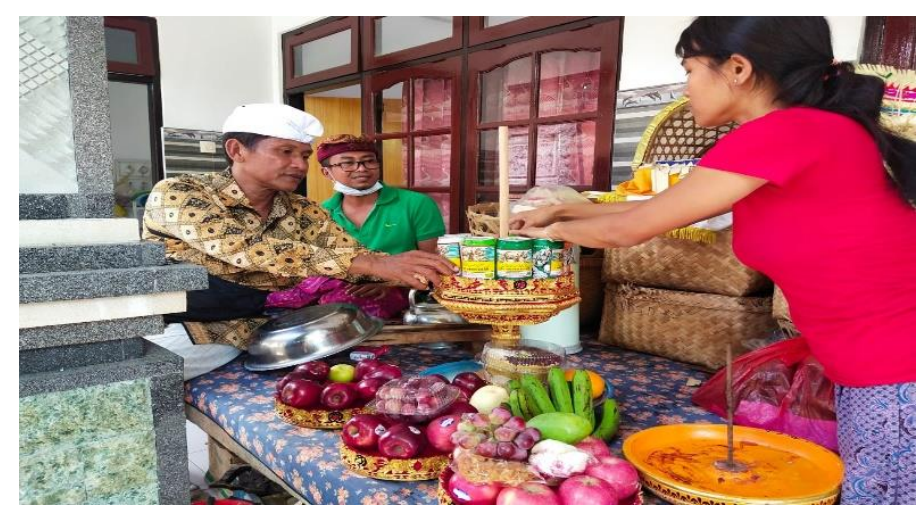

Gambar 3: Merangkai Banten Gebogan dengan Minuman Kaleng Sumber : (Dokumen : Penulis, 2020)

\subsubsection{Praktis, Efektif dan Efisien}

Praktis merupakan suatu cara yang dianggap lebih mudah untuk membantu kita dalam menjalankan sesuatu hingga mencapai tujuan yang kita inginkan. Sedangkan efisiensi adalah usaha pada produksi untuk memberantas segala pemborosan bahan dan tenaga kerja maupun gejala yang merugikan. Selanjutnya pengertian efisiensi terus berkembang meliputi hampir semua bidang ilmu pengetahuan. Bekerja dengan efisien adalah bekerja dengangerakan, usaha, waktu dan kelelahan yang sedikit mungkin (Soewarni, 2010 : 100). Sedangkan Husman (2011 : 2) mengatakan bahwa Efisien (daya guna) adalah proses penghematan 7M + 1I (ma, money, material, machines, methods, marketing, minutes + informasi) dengan cara melakukan pekerjaan dengan benar (do things right), sedangkan efektif (hasil guna) adalah tingkat keberhasilan pencapaian tujuan (outcomes)dengan cara melakukan pekerjaan yang benar (do the right things).

Selanjutnya Steers mengemukakan bahwa efektivitas adalah jangkauan usaha suatu program sebagai suatu sistem dengan sumber daya dan sasaran tertentu (Steers, 1985 : 87). Sedangkan menurut kamus Ilmiah Popular Kontemporer efektivitas berarti ketepat gunaan atau menunjang tujuan (Alex, $2005: 138)$. 
Terkait uraian diatas tentang banten gebogan menggunakan minuman kaleng / hasil pabrikan lainnya terbilang cukup praktis, efektif dan efisien dapat kita jumpai dalam studi wawancara pada informan sebagai berikut.

...tiang ngaryanin banten gebogan nganggen sarana merupa minuman kaleng lan seluir ipun uli hasil pabrikan wantah apang lebih elah-aluh menatane, praktis, lan engal pragat. Sasukat tiang nganggen minuman kaleng, banten gebogan punika lebih mudah ditata, tinggal ngejang ngejang maten ring dulang ten perlu ribet malih karane ukuran minuman kaleng nika pateh, ten sekadi yen nganggen whowohan nika harus medaging ngerereh ane pateh ukurane apang ngenah becik. Sedurungne biasane tiang ngaryanin banten gebogan tiang bisa kanti 1 jam, nanging sekat tiang nganggen sarana minuman kaleng puniki wiwah minuman/makanan hasil pabrikan sane lianan, galah antuk ngaryanin gebogan puniki lebih enggal 30 menit mangkin sampun pragat...

Terjemahannya:

...saya membuat banten gebogan menggunakan sarana berupa minuman kaleng dan sebagainya dari hasil pabrikan supaya lebih gampang simpel menatanya, praktis, dan cepat seslesai dalam pempuatannya. Semenjak saya menggunakan bahan minuman kaleng, banten gebogan itu lebih mudah ditata, tinggal menaruh saja minuman kaleng tersebut pada sebuah dulang tersebut tidak perlu ribet lagi karena ukuran minuman kaleng itu sama, tidak seperti kalua menggunakan buah-buahan itu harus menyortir terlebih dahulu mencari ukuran yang sama biar keliatan bagus. Sebelumnya biasannya saya membuat banten gebogan bisa sampai 1 jam, namun setelah saya menggunakan minuman kaleng ini atau minuman/makan hasil pabrikan yang lainnya, waktu untuk membuat banten gebogan ini sekarang bisa menjadi lebih cepat 30 menit sudah selesai...(wawancara, 8 Oktober 2020).

Pernyataan informan di atas menunjukan bahwa alasan menggunakan minuman kaleng untuk banten gebogan karena kepraktisanya mudah ditata karena dari segi ukuran minuman kaleng itu ukurannya pasti sama dari pada buah-buahan pada ummumnya yang mana harus menyortir buah-buahan tersebut mencari supaya ukurannya sama. Data di atas juga menunjukan keefektifan dari segi waktu, dari biasanya pembuatan banten gebogan dibuat sampai 1 jam, tapi sekarang semenjak menggunakan minuman kaleng pembuatan banten gebogan tersebut menjadi sedikit lebih cepat selesai dari sebelumnya. Senada dengan yang diungkapkan oleh Ni Made Yuliani menyatakan bahwa:

...tiang ngaryanin banten gebogan nganggen minuman kaleng wantah praktis, enggal pragat ketimbang nganggen bahan sane lianan. Banten gebogan punika keaturuang dumun ke luhur, risampune keaturang dados lungsuran, lungsurang sane saking minuman kaleng punika lebih awet lan tahan lama ketimbang sane lianan mekadi sarwa who-wohan punika wantah enggal berek yen nengil makelo lan ten becik antuk ngajeng. Napi malih yen nuju rerainan harga who-hohan nika pastika ngancan ngemaelan, kebanding minuman kaleng punika lebih mudah hargane. Mewanin sekadi punika makane tiang seneng nganggen sarwa minuman kaleng keanggen banten gebogan... 
Terjemahannya:

...saya membuat banten gebogan dengan menggunakan minuman kaleng supaya lebih praktis, lebih cepat selesai daripada menggunakan bahanbahan yang lainnya. Banten geboban itu dihaturkan dulu kehadapan Tuhan, setelah selesai dihaturkan minuman kaleng itu lebih awet dan tahan lama dibandingkan bahan yang lainnya seperti bahan dari buah-buahan yang cepat busuk kalau didiamkan dalam waktu yang lama dan tidak layak untuk dikonsumsi. Apalagi kalau musim hari raya harga buah-buahan itu pasti lebih mahal, dibandingkan minuman kaleng yang mana harganya terbilang lebih murah. Maka dari pada itu makanya saya lebih senang menggunakan aneka ragam minuman kaleng untuk bahan pembuatan banten gebogan...(wawancara, 9 Oktober 2020).

Data di atas menunjukan bahwa, penggunaan minuman kaleng sebagai bahan pembuatan banten gebogan dirasa lebih praktis karena lebih mudah menatanya, dan efesien dari segi waktu lebih cepat selesai dalam pembuatannya. Data di atas juga menunjukan bahwa pemilihan minuman kaleng sebagai bahan banten gebogan terbilang lebih efektif, karena minuman kaleng tersebut lebih awet atau tahan lebih lama dari pada bahan yang lainnya lebih cepat busuk bila tidak segera dikonsumsi. Bahan minuman kaleng lebih efisensi dari segi harga karena relatif lebih murah dari pada harga buah-buahan, apalagi harga buah-buahan menjelang hari-hari raya harganya pasti akan relatif lebih mahal dari pada minuman kaleng.

\subsection{Implikasi Banten Gebogan Modern}

\subsubsection{Degradasi Spiritual}

Menurut kamus besar bahasa Indonesia degradasi adalah kemunduran atau kemerosotan, dan menurut Immanuel Kant moralitas adalah hal keyakinan dan sikap bathin dan bukan hal sekedar penyesuaian aturan dari luar, entah itu aturan hukum Negara, agama atau adat istiadat. Sedangkan menurut Robert J. Havighurst moral yang bersumber dari adanya suatu tata nilai yakni a value is an obyect estate or affair wich is desired (suatu obyek rohani atas suatu keadaan yang di inginkan). Maka kondisi atau potensi internal kejiwaan seseorang untuk dapat melakukan hal-hal yang baik sesuai dengan nilai-nilai value yang diinginkan itu (Ahmadi dan Sholeh, 2005 : 104). Sedangkan Spiritual dalam Kamus Besar Bahasa Indonesia (1998 : 857) berasal dari kata spirit yang berarti "semangat, jiwa, roh,sukma, mental, batin, rohani dan keagamaan". Sedangkan Anshari (1995 : 653) dalam kamus psikologi mengatakan bahwa spiritual adalah asumsi mengenai nilai-nilai transendental. Degradasi spiritual dapat diartikan sebagai kemerosotan mental batin maupun moralitas seseorang. Terkait dengan uraian di atas banten gebogan juga mengalami degradasi spiritual. Seperti yang di dikutip dalam Bali Expres online sebagai berikut.

Meski berbentuk mengerucut, banten gebogan ini tidak perlu dibuat besar. Karena menurut Ida Rsi Bhujangga Waisnawa Putra Sara Shri Satya Jyoti, inti dari banten gebogan adalah Panca Rengga, yakni lima macam buah-buahan yang berasal dari lima jenis kelahiran. Mulai dari buah yang berasal dari bunga hingga 
buah yang berasal dari akar tanaman. Jika ini diabaikan, jelas nilai spiritualnya lenyap. Kelima buah dengan asal atau kelahiran yang berbeda ini, lanjut Ida Rsi, harus ada dalam sebuah gebogan. "Sehingga, bagaimana pun megah dan mahalnya buah-buahan serta penganan yang digunakan dalam membuat gebogan ini, jika unsur Panca Rengga ini tidak ada, maka nilai spiritual dari gebogan ini tidak akan ada," ungkapnya. (https://baliexpress.jawapos.com).

Ditegaskan Ida Rsi, unsur dari Panca Rengga yang mampu mewakili seluruh isi alam. Dengan adanya unsur Panca Rengga ini, lanjutnya, maka nilai spiritual dari gebogan ini tetap tinggi, meskipun dibuat tidak terlalu megah dan tinggi. Adapun buah yang termasuk dalam Panca Rengga ini , terdiri dari unsur buah-buahan yang dalam keberadaannya atau kelahirannya berbeda-beda. Ida Rsi mencontohkan, buah yang lahir dari bunga seperti mangga, apel, jeruk, jambu. Selanjutnya adalah buah yang ada sekali bebuah, pohonnya langsung mati, seperti pisang. Yang ketiga adalah buah yang lahir langsung dari pohonnya, di antaranya nangka, durian, duku leci. Selanjutnya adalah buah bersisik, seperti nanas, salak, buah naga. Yang terakhir adalah buah yang berasal dari akar, seperti bengkuang, sabrang, dan ketela. Kelima macam kelahiran buah-buahan ini wajib digunakan dalam sebuah gebogan, sehingga bisa memiliki nilai spiritual yang tinggi. "Selain itu, dalam gebogan ini, juga wajib menggunakan penganan, yang dalam tradisi umat Hindu di Bali biasanya menggunakan jajan Begina dan jajan Uli yang terbuat dari ketan," lanjutnya. Untuk menjadi sebuah persembahan, gebogan ini berisikan canang atau sampian yang umumnya disebut dengan Sampian gebogan. “Unsur Sampian Gebogan inilah merupakasn wujud persembahan dan bhakti kehadapan Tuhan sebagai sang pencipta alam semesta," terangnya. Selain itu, gebogan juga berisikan hiasan berupa bunga yang ditusukan pada bagian atas. "Bunga ini, selain sebagai salah satu bentuk persembahan, juga sebagai bentuk keindahan dari alam semesta itu sendiri. Selain sebagai bentuk persembahan, gebogan juga mengandung unsur keindahan dalam sebuah persembahan (https://baliexpress.jawapos.com).

Data di atas menunjukan bahwa, memang suatu perubahan tidak bisa dipungkiri seiring berjalanannya waktu. Seperti banten gebogan mengalami suatu pergeseran akibat pengaruh modernisasi dewasa ini khususnya di Desa Abiantuwung. Tidak hanya unsur estetikanya saja yang kita bisa petik di dalam banten gebogan tersebut. Banten gebogan tersebut memiliki esensi dan filosofi mendalam seperti yang diungkapkan oleh Ida Rsi Bhujangga Waisnawa Putra Sara Shri Satya Jyoti. Dewasa ini kebanyakan masyarakat Hindu Bali mengesampingkan tatwa dari sebuah banten, khusunya pada banten gebogan. Banten gebogan tersebut menjadi mengalami degradasi spiritual akibat pengaruh modernisasi dapat dilihat dari berbagai aneka ragam minuman kaleng dan sebagainya dari hasil pabrikan yang digunakan dalam bahan pembuantan banten gebogan. Padahal sesungguhnya banten gebogan itu sendiri sudah memiliki pakem-pakem tersendiri seperti yang disebutkan oleh Ida Rsi Bhujangga Waisnawa Putra Sara Shri Satya Jyoti, seperti bahan banten gebogan itu harus memakai pakem Panca Rengga, yakni lima macam buah-buahan yang berasal 
dari lima jenis kelahiran. Mulai dari buah yang berasal dari bunga hingga buah yang berasal dari akar tanaman.

Suratan sloka Bhagawadgita dengan jelas bahkan tegas telah mengelompokkan tingkatan yajña berdasarkan kualitasnya. Ukuran kualitas, tidak berkaitan dengan unsur besaran kuantitas material tetapi lebih kepada landasan keyakinan serta motif bhakti yang menyertainya. Sehingga jika diringkas, tingkatan kualitas yajña itu dipilah menjadi tiga (3) tingkatan, yaitu : Tamasika yajna, Rajasika yajña, dan Satwika yajña (Maswinara, 1997 : 469-470).

Kurangnya pemahaman umat Hindu khususnya di desa Abianuwung tentang sastra dan tatwa agama dalam pembuatan banten khususnya banten gebogan, membuat nilai spiritual dari sebuah banten itu menjadi menurun atau berada dalam kategori tamasika yajña atau mengalami degradasi spiritual. Walaupun persembahan itu kita haturkan dengan hati suci yang tulus iklas kehadapan Tuhan, tetapi nilai filosofi dan spirit dari sebuah banten itu harus juga kita perhatikan, karena kita hidup beragama itu harus berdasarkan sastra agama, untuk mencapai Moksartham jagaditha ya ca iti Dharma.

\subsubsection{Transformasi Kebudayaan}

Kata transformasi berasal dari kata dalam bahasa Inggris transform, yang berarti mengendalikan suatu bentuk dari satu bentuk ke bentuk yang lain. Jadi transformasi sosial budaya berarti membicarakan tentang proses perubahan struktur, sistem sosial, dan budaya. Transformasi di suatu pihak dapat mengandung arti prosesperubahan atau pembaharuan struktur sosial, sedang di pihak lain mengandung makna proses perubahan nilai. Kita hidup di dunia ini terus berubah. Masyarakat dan kebudayaannya terus menerus mengalami perubahan. Kebiasaannya, aturan- aturan kesusilaannya, hukumnya, lembagalembaganya terus berubah. Dan semua perubahan. Menurut Kamus Bahasa Indonesia transformasi adalah perubahan, berubah dari keadaan yang sebelumnya menjadi baru sama sekali (Polak, 1985 - 385).

Menurut Kamus Besar Bahasa Indonesia (200 : 169) budaya artinya pikiran, akal budi,hasil, adat istiadat atau sesuatu yang sudah menjadi kebiasaan yang sukar diubah. Menurut C. Greertz (1973) dalam Fedyani (2005: 289), mengemukakan bahwa definisi kebudayaan sebagai : (1) suatu sistem keteraturan dari makna dan simbol-simbol, dimana makna dan simbol tersebut individu mendefinisikan dunia mereka, mengekpresikan perasaan-perasaan mereka dan membuat penilaian mereka; (2) suatu pola makna-makna yang ditransmisikan secara historis yang terkandung dalam bentuk-bentuk simbolik, dimana melalui bentuk-bentuk simbolik tersebut manusia berkomunikasi, memantapkan dan mengembangkan pengetahuan mereka mengenai dan bersikap terhadap lingkungan; (3) suatu peralatan simbolik bagi mengontrol perilaku, sumber-sumber ekstrasomatik dari informasi; dan (4) kebudayaan adalah suatu sistem simbol, maka proses kebudayaan harus dipahami, diterjemahkan dan diinterpretasi.

Dari uraian di atas transformasi kebudayaan sangat terasa dapat kita lihat dari bahan yang digunakan sebelumnya dalam pembuatan banten gebogan oleh umat Hindu di desa Abiantuwung, yang pada intinya banten gebogan tradisional hanya menggunakan bahan-bahan alami seperti buah-buahan, bunga, janur dari 
hasil bumi, tetapi nampaknya sekarang umat Hindu di desa Abiantuwung sudah mulai menggunakan berbagai ragam bahan dari minuman kaleng dan sebagainya dari hasil pabrikan. Perubahan dari banten gebogan tradisional ke modern tersebut menunjukan adanya transformasi kebudayaan.

\section{PENUTUP}

Banten gebogan sudah mengalami pergeseran dan perubahan ke arah modernisasi, yakni dengan menggunakan berbagai bahan dari hasil pabrikan, baik berupa minuman kaleng dan sebagainya. Adapun alasan masyarakat yang membuat banten gebogan dari minuman kaleng karena lebih estetis, praktis, efektif dan efisien. Penggunaan minuman kaleng dan bahan lainnya dari hasil pabrikan dalam pembuatan banten gebogan memiliki beberapa implikasi diantaranya, degradasi spiritual dan transformasi kebudayaan.

Degradasi spiritual: Dewasa ini kebanyakan masyarakat Hindu Bali mengesampingkan tatwa dari sebuah banten, khusunya pada banten gebogan. Banten gebogan tersebut mengalami degradasi spiritual akibat pengaruh modernisasi dapat dilihat dari berbagai aneka ragam minuman kaleng dan sebagainya dari hasil pabrikan yang digunakan dalam bahan pembuantan banten gebogan. Padahal sesungguhnya banten gebogan itu sendiri sudah memiliki pakem-pakem tersendiri seperti yang disebutkan oleh Ida Rsi Bhujangga Waisnawa Putra Sara Shri Satya Jyoti, seperti bahan banten gebogan itu harus memakai pakem Panca Rengga, yakni lima macam buah-buahan yang berasal dari lima jenis kelahiran. Mulai dari buah yang berasal dari bunga hingga buah yang berasal dari akar tanaman. Jika seseorang dalam dalam melakukan bakti persembahan kehadapan Tuhan dengan tidak mengindahkan sastra agama, itu termasuk dalam tamasika yajña.

Kemudian transformasi kebudayaan dapat kita lihat dari bahan yang digunakan sebelumnya dalam pembuatan gebogan, yang pada intinya banten gebogan tradisional hanya menggunakan bahan-bahan alami seperti buahbuahan, bunga, janur dari hasil bumi, tetapi nampaknya sekarang sudah mulai menggunakan berbagai ragam bahan dari minuman kaleng dan sebagainya dari hasil pabrikan. Perubahan dari banten gebogan tradisional ke modern tersebut menunjukan adanya transformasi kebudayaan.

\section{DAFTAR PUSTAKA}

Ahmadi, Abu dan Sholeh, Munawar. 2005. Psikologi Perkembangan. Jakarta: PT Rineka Cipta.

Alex. 2005. Kamus Ilmiah Popular Kontemporer. Surabaya: Karya Harapan.

Anshari. 1995. Kamus Psikologi. Surabaya: Usaha Nasional.

Departemen Pendidikan Indonesia. 2008. Kamus Besar Bahasa Indonesia. Jakarta: Balai Pustaka.

Fedyani, Achmad Saifuddin. 2005. Antropologi Kotemporer. Jakarta:Kencana.

Husman, Husaini. 2011. Manajemen Teori Praktik dan Riset Pendidikan. Jakarta: PT Bumi Aksara. 
Martono, Nanang. 2012. Sosiologi Perubahan Sosial. Jakarta: PT. Rajagrafindo Persada.

Maswinara, I Wayan. 1997. Dewa-Dewi Hindu. Surabaya : Paramita

Oka Netra, Anak Agung Gede. 1997. Tuntunan Dasar Agama Hindu. Jakarta: Hanoman Sakti.

Polak, Mayor. 1985. Sosiologi. Jakarta : Pt. Ichtiar Baru.

Purba, Mauly. 2007. Musik Tradisional Masyarakat Sumatera Utara. Medan.

Soewarni, Handayaningrat. 2010. Pengantar Studi Ilmu Administrasi dan Manajemen. Jakarta: Haji Masanggung.

Steers, Richard. M. 1985. Efektivitas Organisasi Kaidah Perilaku (Alih Bahasa Magdalena). Jakarta : Erlangga

Tim Penyusun. 2003. Panca Yadnya. Denpasar : Tanpa Penerbit.

Wiana, I Ketut. (2007). Tri Hita Karana, Menurut Konsep Hindu. Surabaya: Paramita.

Sumber Internet:

https://baliexpress.jawapos.com/read/2017/07/16/1424/abaikan-panca rengga-dalam-gebogan-nilai-spiritual-lenyap

http://www.infobintaro.com/makna-adanya-gebogan-dalam-tradisi-hindu-dibali/https://www.kbbi.web.id/praktis 